\title{
Teater Kanvas: Transformasi Ideologi Pertunjukan Menuju Media Dakwah
}

\author{
Nurkholis Makki dan Tasman \\ UIN Syarif Hidayatullah Jakarta \\ nurkholismakki@gmail.com;tasman@uinjkt.ac.id;
}

\begin{abstract}
:
The debate between Islam as a religion or ideology and the political wheel in the New Order regime is full of dynamics. From the beginning of the New Order until the late 1980s Islam in Indonesia was largely outside the arena of power (Sukamto, 2008: 4). However, in the early 1990s Suharto as president began to embrace Islam. The change in the regime's attitude had an impact on the emergence of various Islamic studies and in the end came into contact with art groups. One of them is the theater group in Jakarta, led by Zak Sorga, namely Teater Canvas, which in the end transformed the ideology of its performance into an Islamic Theatre. The question in this research is how is the process of ideological transformation of the Canvas Theater performance and why did the Canvas Theater perform an ideological transformation in its performance? This research is a qualitative research using an ethnographic approachwhich inted to see how the process of transforming ideology of performance in one of the theater groups in Jakarta, namely Teater Kanvas. In this research, researchers used interview data, performance scriptand news clippings about the performance, or exclusive news about the Teater Kanvas whos taken from October 2019 to July 2020. The results of this study are the process of transforming the ideology of the Teater Kanvas performance which consists of three phases: The initial ideological phase of the performance, the ideological transition phase of the performance, and the new ideological phase of the Teater Kanvas performance.
\end{abstract}

Keywords: theater, transformation, performance 


\begin{abstract}
Abstrak:
Perdebatan antara Islam sebagai agama ataupun ideologi dengan roda perpolitikan di masa orde baru penuh dengan dinamika. Di masa awal Orde Baru sampai akhir tahun 1980-an Islam di Indonesia banyak berada di luar arena kekuasaan (Sukamto, 2008: 4). Namun di awal tahun 1990- an Suharto mulai merangkul kalangan Islam. Perubahan sikap rezim tersebut berdampak pada munculnya berbagai kajian-kajian keislaman dan pada akhirnya bersentuhan dengan kelompok kesenian. Salah satunya adalah kelompok teater di Jakarta yang dimotori oleh Zak Sorga, yaitu Teater Kanvas yang pada akhirnya mentransformasikan ideologi pertunjukannya menjadi sebuah pertunjukan Teater Islami. Yang menjadi pertanyaan dalam penelitian ini adalah bagaimana proses transformasi ideologi pertunjukan Teater Kanvas dan mengapa Teater Kanvas melakukan transformasi ideologi dalam pertunjukannya? Penelitian ini bertujuan mengetahui bagaimana proses transformasi ideologi Teater Kanvas dari ideologi alienasi menjadi Teater Islami. Dari proses tersebut penulis ingin mengetahui penyebab teater kanvas melakukan transformasi ideologi dalam pertunjukannya dan melihat dampak transformasi ideologi tersebut terhadap pertunjukan mereka. Penelitian ini menggunakan metode kualitatif dengan pendekatan etnografi yang bertujuan untuk melihat bagaimana proses transformasi ideologi pertunjukan pada salah satu kelompok Teater di Jakarta, yaitu Teater Kanvas. Dalam penelitian ini peneliti menggunakan data wawancara, naskah pertunjukan dan beberapa kliping pemberitaan seputar pertunjukan, ataupun pemberitaan ekslusif tentang Teater Kanvasyang diambil pada Oktober 2019 hingga Juli 2020. Hasil penelitian ini adalah proses transformasi Ideologi pertunjukan Teater Kanvas terdiri dari tiga fase, yaitu; fase ideologi pertunjukan awal, fase transisi ideologi pertunjukan dan fase ideologi baru pertunjukan Teater Kanvas.
\end{abstract}

Kata kunci : teater, transformasi, pertunjukan, ideologi

Permalink/DOI: http://doi.org/10.15408/dakwah.v25i1.23176

\section{Pendahuluan}

Perkembangan teori komunikasi dan budaya kritis pada tahun-tahun terakhir ini telah membawa serta pada pembahasan ideologi. ${ }^{1} \quad$ Menurut Lull

${ }^{1}$ Dalam pengertian paling umum ideologi adalah pikiran yang terorganisir, yaitu berupa nilai, orientasi, dan kecendrungan yang saling
(1998:1) ideologi adalah sistem ide-ide yang diungkapkan melalui komunikasi. Pada penerapannya dalam proses mentransfer ideologi dibutuhkan sebuah

melengkapi sehingga membentuk perspektifperspektif ide yang diungkapkan melaui komunikasi dengan media teknologi dan komunikasi antar pribadi. 
media yang berfungsi sebagai perantara atas berpindahnya pemahaman tentang ideologi tersebut dari komunikator kepada komunikan. Terdapat berbagai media untuk mentransmisikan ideologi tersebut, salah satu media yang digunakan untuk mentransfer ideologi kepada khalayak adalah media seni pertunjukan, di antaranya adalah seni pertunjukan teater.

Teater merupakan salah satu seni pertunjukan yang kerap digunakan untuk menginformasikan pesan kepada khalayak. Dengan banyaknya unsur yang ada pada pertunjukan teater seperti unsur musik, artistik, dan juga peran, kesenian tersebut menjadi pilihan bagi seniman untuk menyampaikan pesan, gagasan ataupun ideologi mereka kepada penonton. Pemanfaatan teater sebagai media komunikasi sudah digunakan sejak lama dan masih bertahan hingga sekarang. Biarpun demikian waktu dan tempat pertunjukan teater dimulai tidak diketahui secara pasti, namun salah satu teori mengatakan bahwa teater berasal dari upacara agama primitif, yang kemudian ditambahkan unsur cerita dan akhirnya berkembang menjadi sebuah drama pertunjukan. Meskipun upacara agama telah lama ditinggalkan namun teater masih berkembang hingga sekarang (Sumardjo, 1986:1).

Beberapa kelompok teater modern yang berkembang di Indonesia memilik ciri khas serta ideologi dalam pertunjukan tiap-tiap kelompok. Ideologi yang dimaksud tidak berada dalam makna teoritis dan filosofis yang besar, sebagaimana yang dirintis oleh Destrut de Tracy (1796) sebagai sebuah "ilmu tentang gagasan" (ideas). Ideologi mendapat pemahaman di sini sebagai sebuah titik tolak interpretasi, titik tolak dalam memproduksi kode/simbol/tanda dapat terhindar dari resiko bahaya kekeliruan. Dari titik tolak ini pula, menurut Zoest, dimungkinkan tabir prasangka, juga yang berasal dari lambang-lambang pertunjukan (Dahana, 2000: 19). Melalui media pertunjukan teater ideologi tersebut bisa dipertunjukan kepada khalayak, sebab komunikasi seni pertunjukan teater memiliki pola sebagai media komunikasi pendidikan budaya dan lingkungannya.

Pola komunikasi pertunjukan teater demikian pada dasarnya memiliki pola interaktif dengan masyarakat lingkungan yang ingin melibatkan diri dengan cara menonton, mengapresiasi, mengamati, menginterpretasi, dan mengkritisi. Interaksi dalam pertunjukan teater lebih dipandang sebagai interaksi simbolik, yaitu sebagai suatu aktivitas yang merupakan ciri khas manusia dengan cara berkomunikasi atau proses pertukaran simbol yang diberi makna (Mulyana, 2002:68). James R. Bradon dalam bukunya Theatre in Southeast Asiamenjelaskan bahwa pada akhir abad ke-19 dan awal abad 20, ketika negaranegara Eropa dan Amerika Serikat masih menguasai sebagian besar dari negaranegara di Asia Tenggara, para tokoh nasionalis kerap kali menggunakan seni pertunjukan sebagai media untuk membangkitkan semangat rakyat melawan penjajah (Soedarsono, 2003: 208-209).

Pada perkembangan Teater Modern di Indonesia ada beberapa grup yang memiliki kekuatan secara ideologi baik pemikiran ataupun politik dalam pertunjukannya, terlebih beberapa kelompok teater yang lahir di zama orde baru. Sebab di zaman tersebut pergolakan politik teramat kencang, dan resistensi 
terhadap rezim cukup kuat dan banyak disuarakan di panggung-panggung kesenian. Sebagian kelompok teater muncul dari sekelompok individu yang membentuk komunitas, Sebagian lagi lahir dari berbagai kampus di Indonesia. Dalam perjalanan waktunya salah satu ideologi yang masih melekat di beberapa kelompok Teater di Indonesia adalah Islam.

Melacak teater dalam kalangan umat Islam Indonesia, bisa dicatat munculnya himpunan-himpunan seni budaya dalam kalangan umat Islam Indonesia pascapemilu 1955, yang membangun struktur budaya sebagai wacana tandingan untuk membendung pengaruh LEKRA (Lembaga Kesenian Rakyat) yang didirikan Partai Komunis Indonesia (PKI) tahun 1950. Pada tahun 1956, berdirilah Himpunan Seni Budaya Islam (HSBI) yang kemudian pada tahun 1961 membentuk Majelis Seniman Budayawan Islam (MASBI) yang banyak memunculkan pertunjukan-pertunjukan teaternya, baik melalui panggung, radio maupun televisi (Kusumawati, 2009:374). Menurut Hamdy Salad (2000: 98), sampai tahun 1986, HSBI telah memproduksi 510 drama radio, 306 drama panggung, dan 180 drama televisi. Organisasi-organisasi Islam pun tidak ketinggalan membentuk lembagalembaga kesenian, seperti LESBUMI (Nahdlatul Ulama), ISBM (Muhammadiyah), LESKI (Perti) dan LESBRA (al-Washliyah).

Di antara beberapa kelompok teater yang mengusung Islam sebagai ideologi adalah Teater Kanvas. Teater yang dipimpin oleh Zakaria Sorga, atau biasa disebut dengan Zak Sorga ini berdiri di tahun 1987. Seni dan Dakwah Islam merupakan sebuah slogan yang diyakini oleh Teater Kanvas dalam setiap pertunjukannya. Dalam perjalannya Teater Kanvas sudah mementaskan puluhan naskah bertema sosial-kerakyatan bergaya komedi hitam diberbagai kantong-kantong budaya dan kampuskampus di seluruh Indonesia. $^{2}$

Pada proses perjalanannya Teater Kanvas awalnya merupakan sebuah teater kontemporer yang pada akhirnya meyakini Islam sebagai dasar kerja pertunjukannya. Awalnya Zak Sorga selaku pendiri sekaligus sutradara Teater Kanvas kerap menyajikan pertunjukan yang lekat dengan unsur alienasi manusia, hal itu tergambar pada lakon Stasiun Kubur-Kubur, Aljabar, Reuni Orang-Orang, Berbiak dalam Asbak, dan Di Luar Ruang. Pada pertunjukanpertunjukan tersebut Teater Kanvas menyajikan pesan tentaang keterasingan manusia (Sorga, 2019). Setelah itu tampak grup ini menyuguhkan lakonlakon perjuangan Islam: Intifadah (1995), tentang perlawanan Palestina terhadap Israel, Konspirasi (1996), tentang pergulatan politik di Turki, dan Revolusi Burung (1997), tentang centang-perenang dunia pendidikan di Indonesia (Danarto, 1998). Hingga saat ini Teater Kanvas masih konsisten memproduksi dengan nilai-nilai keislaman, sesuai dengan slogan mereka, yaitu Seni dan Dakwah Islam dan mempunyai penonton setia yang bersedia meluangkan waktunya di setiap pertunjukan teater kanvas.

Transformasi dari ideologi Teater Kanvas menjadi sebuah hal yang menarik

2

https://teaterkanvas.wordpress.com/tentangte aterkanvas/ diakses pada tanggal 1 Agustus, 2020 (12: 50 WIB) 
untuk diteliti, karena selain proses transformasi yang dilakukan kelompok ini bertepatan dengan perubahan sikap rezim orde baru terhadap Islam, tulisan ini mengetahui tentang landasan ataupun alasan mengapa Teater Kanvas mengubah arah ideologi kelompoknya. Setiap perubahan atau transformasi tentu mempunyai resiko dan dalam penelitian ini penulis akan mencoba melihat bagaimana proses sebuah transformasi ideologi dalam pertunjukan sebuah kelompok teater.Teater sebagai media komunikasi tergambar melalui proses komunikasi model makro. Dalam hal ini merupakan sebuah landasan yang melatar belakangi penelitian yang penulisan. Selain sebagai sebuah seni, Teater juga merupakan sebuah media untuk menyampaikan pesan kepada khalayak. Ilmu komunikasi dalam penelitian ini terdapat pada sebuah proses penyampaian pesan ideologi kepada penerima pesan, dalam penelitian ini ada tiga atau penerima pesan yang akan penulis teliti terkait transformasi ideologi, yaitu; penonton, pemain, dan pemberi pesan (sutradara/penulis naskah). Selain dalam ilmu komunikasi, ilmu dakwah juga melatarbelakangi penulis mengambil tema penelitian tentang ini. Dalam hal ini objek yang menjadi penelitian penulis adalah Teater Kanvas yang merupakan kelompok teater yang konsisten berdakwah dengan menggunakan media seni pertunjukan.

Pendekatan yang digunakan dalam penelitian kualitatif ini adalah pendekatan etnografi. Mengutip pendapat Sibarani (2012: 243) mengatakan bahwa pendekatan etnografi masih mempunyai relevansi untuk diterapkan dalam penelitian tradisi lisan, dalam konteks penelitian ini adalah teater sebagai sebuah budaya seni tradisi lisan. Spradley (2007: 17) mengemukakan bahwa salah satu kegunaan etnografi adalah untuk memahami masyarakat yang kompleks atau kebudayaan kita sendiri, dan kita bisa memahami sesuatu hal yang dilihat dan didengarkan untuk menyimpulkan hal yang diketahui orang.

Penelitian ini dilaksanakan dengan beberapa tahap. Tahap pertama, penelitian lapangan (field research). Langkah pertama yang dilakukan peneliti adalah melakukan pengamatan terlibat (participant observation). Pada tahap ini penulis mengamati bagaimana sebuah proses transformasi ideologi melalui beberapa naskah pertunjukan yang pernah dimainkan oleh Teater Kanvas dan mengamati masyarakat penikmat Teater Kanvas baik secara langsung atau melalui berbagai pemberitaan di media. Sesuai dengan yang dikemukakan oleh Spradley (2007) bahwa seorang etnografer harus sering mengumpulkan banyak data dengan pengamatan terlibat dan melakukan berbagai macam percakapan seperti layaknya persahabatan.

Selain melakukan pengamatan terlibat, peneliti juga harus menentukan informan. Dalam menentukan siapa informan yang diperlukan, peneliti harus cermat dalam memilih orang-orang (informan) yang akan diwawancarai (Emzir, 2012: 53).Pada prinsipnya menghendaki seorang informan itu harus paham terhadap budaya yang dibutuhkan. Hal ini dilakukan dengan maksud agar peneliti bisa mendapatkan data-data penelitian dengan lengkap sehingga menghasilkan penelitian yang baik. Setelah itu, penelitimengadakan wawancara (interview) kepada para informan (Rustanto, 2015: 58). Secara garis besar pedoman wawancara ada dua 
macama yaitu, yang pertama pedoman wawancara tidak terstruktur, yaitu pedoman wawancara yang hanya memuat garis besar yang akan ditanyakan. Dalam hal ini perlu adanya kreatifitas dari pewawancara. Yang kedua pedoman wawancara mendalam, yaitu pedoman wawancara yang disusun dengan tujuan mendapatkan informasi sebanyakbanyaknya dari informan. Pewawancara memungkinkan untuk mendapatkan informasi lain dari nara sumber yang selanjutnya, yang diketahui dari nara sumber sebelumnya. Format dan model wawancara disusun sedemikian rupa yang dimulai dari perlunya mengetahui bentuk dan transformasi ideologi pertunjukan Teater Kanvas.

\section{Teater Indonesia dalam sejarah}

Seni pertunjukan dan berbagi macam bentuk ekspresi kebudayaan sejak lama dipandang penting di kehidupan politik Indonesia. Jennifer Lindsay mencatat, sejumlah tokoh penting pemerintahan turut menghadiri kongreskongres kebudayaan di masa awal kemerdekaan. Ia juga mecatat banyak misi-misi kebudayaan yang dikirim ke luar negeri oleh Presiden Soekarno pada tahun 1950-an dan 1960-an. Misi yang biasanya beranggotakan penari dan musisi ini bertujuan sebagai ekspresi "kepercayaan diri dan kebanggaan bangsa" (Lindsay, 2012: 95). Menciptakan kebudayaan nasional yang maju untuk bangsa Indonesia yang baru adalah tujuan umum selama masa-masa tersebut. Para seniman, penulis, intelektual, organisasi, politik hingga pejabat pemerintahan berlomba-lomba menunjukan visi mereka tentang bangsa Indonesia dan kebudayaan (Hartley, 2014:4). Salah satu seni pertunjukan yang mempunyai akar penting terhadap kebudayaan di Indonesia adalah seni pertunjukan teater. Pasca kemerdekaan Indonesia, teater semakin melembaga untuk membentuk institusi pendidikan tersendiri. Lembaga pendidikan teater dibentuk oleh tokoh-tokoh yang sebelumnya telah terjun langsung di dunia teater, seperti di Jakarta pada tahun 1955 muncul Akademi Teater Nasional Indonesia (ATNI) yang dimulai oleh Usmar Ismail dan Asrul Sani dan dilanjutkan aktor dan sutradara lulusan akademi tersebut, seperti Teguh Karya, Wahyu Sihombing, Tatiek Malyati, Pramana Padmadarmaya, Galib Husein, dan Kasim Achmad. Selain itu di Yogyakarta pada tahun itu muncul juga institusi yang mempelajari teater seperti Akedemi Seni Drama dan Film (ASDRAFI) yang dipelopori oleh Harymawan dan Sri Murtono, dan di Solo didirikan pula institusi yang mengajarkan teater dengan membentuk Himpunan Seni Budaya Surakarta (HBS) (Jaeni, 2019: 1130).

Dalam sejarah perkembangan teater di Indonesia, kita kerap kali disajikan oleh berbagai macam kelompok dan berbagai macam gagasan yang diangkat oleh masing-masing kelompok teater. Mulai dari Bengkel Teater (WS. Rendra), Teater Populer (Teguh Karya), Studiklub Teater Bandung (Jim Lim), Teater Kecil (Arifin C Noer), Teater Mandiri (Putu Wijaya), Teater Koma (Nano Riantiarno) dan berbagai macam teater lain di Indonesia. Teater modern Indonesia yang mempunyai warna Islam menjadi minoritas di tengah-tengah mayoritas penduduk Indonesia yang beragama Islam. Suatu kondisi yang ironis mengingat teater yang bernafaskan Islam termarjinalkan. Kelompok teater 
yang mampu memberikan kontribusi bagi perkembangan teater yang bercorak Islam satu persatu berguguran (Arisona, 2012:75).

Di Indonesia berbagai kelompok teater mempunyai ciri dan pesan yang berbeda, namun dari berbagai macam grup tersebut hanya sedikit yang menyiarkan tentang dakwah Islam. Jika kita berkaca dari beberapa nilai dakwah di atas, sebenarnya banyak pesan Islam yang bisa digaungkan melalui media panggung. Meskipun begitu bukan berarti tidak ada grup ataupun sanggar yang tidak mempunyai nafas keislaman.

Salah satu grup teater yang konsisten menyiarkan nafas keislaman adalah Teater Kanvas. Didirikan pada tahun 1987 oleh Zak Sorga. Keberadaan Teater Kanvas merupakan sebuah anomali di mana kebanyakan grup teater di saat itu tidak menjadikan panggung teater sebagai sarana dakwah. Sebagai mana pendapat Bourdieu (2010:16) sebuah karya seni tidak terlepas dari dominasi karya seni yang lain untuk memperoleh posisi dalam arena sosial. Karya seni sendiri pada hakekatnya merupakan produk arena sosial secara keseluruhan (Arisona, 2012:75). Dalam hal ini, arena sosial yang dimaksud adalah konteks keadaan di masa awal Teater Kanvas memlih jalur dakwah Islam sebagai ideologinya, pada saat itu arena sosial perkembangan teater lebih didominasi berbagai teater kontemporer yang mengusung berbagai macam ideologi.

Teater Kanvas bisa dibilang sebagai teater terpadu, sebabpada bebreapa pementasannya terintegrasi dengan bazar yang mereka buat, baik busana, buku, kaset, ataupun cendera mata yang erat dengan simbol Islam. Hal tersebut menyiratkan grup ini kelihatan piawai dalam mengumpulkan massa melainkan juga memutar keuangan. Selain itu dalam usahanya menerapakn nilai Islam, pada pertunjukannya Teater Kanvas melakukan pemisahan antara penonton lelaki dan perempuan. Meski penonton dipisahkan antara yang lelaki dan perempuan, para penontonnya tidak mempermasalahkan hal tersebut. Bahkan beberapa penonton rela membawa bayibayi untuk menonton pertunjukan Teater Kanvas di udara terbuka sampai tengah malam (Danarto, 1998).

Teater Kanvas juga mempunyai hubungan yang cukup erat dengan salah satu partai Islam di Indonesia, yaitu Partai Keadilan Sejahtera (PKS). Sebagai anggota Partai Keadilan, Zak Sorga merupakan aset yang mahal bagi partai, lebih-lebih untuk masa-masa mendatang. Selain itu pengembangan seni dan budaya menjadi perhatian serius Partai Keadilan Sejahtera (PKS). Sebagai tindaklanjutnya, PKS kerap mengadakan kerja sama dengan Teater Kanvas. Di antaranya adalah dengan menggelar pementasan teater bertajuk "Penghuni Kapal Selam"di Gedung Kesenian Jakarta, Pasar Baru, Jakarta Pusat. Selama tiga malam penyelenggaraan, dalam pertunjukan tersebut tidak kurang dari 1.500 penonton yang hadir menyaksikan pertunjukan dan didominasi oleh penonton-penonton muda (Republika Online, 2014).

Sebagai komunitas teater yang berjiwa islami, Teater Kanvas telah dua kali menjadi bahan riset mahasiwa yang meneliti tentang kisi-kisi ke-islamannya, salah satunya yang ditulis oleh Siska Dharmayantie SPA. S.Sos.I yang berjudul Teater Sebagai Sarana Dakwah (Suatu tinjauan terhadap Teater Kanvas Jakarta) di Fakultas Agama Islam 
Universitas Islam As-Syafi'iyah. Selain menjadi sebuah objek riset, fenomena Teater Kanvas mengundang komentar yang beragam dari beberapa pengamat seni dan Seniman di antaranya: Danarto, Syu'bah Asa, Chaerul Umam, Pepeng dan seniman-seniman lain. (Teaterkavas.wordpress.com).

\section{Berdirinya Teater Kanvas}

Pendiri dan salah satu tokoh penting dalam berkembangnya Teater Kanvas adalah Zak Sorga. Bernama asli Zakaria Sorga ia dilahirkan di Tuban, Jawa Timur, 8 Januari 1964. Tuban merupakan salah satu Kabupaten di Jawa Timur yang kental dengan nuansa keagamaannya. Hal ini dapat dilihat dari sloga Kabupaten Tuban, yaitu Bumi Wali, sebab Tuban merupakan salah satu tempat berkumpul para Walisongo. Ini dapat dilihat dari banyaknya makam wali yang berada di kota tersebut, seperti Sunan Bonang, Syaikh Maulanalbrahim Asmaraqandi, Sunan Bejagung, Syaikh Achmad Kholil, dan lain-lain. Pada masa kecilnya Zak Sorga hidup di lingkungan yang dekat dengan unsur keagamaan, sebab di wilayahnya banyak pesantrenpesantren yang membuka lembaganya untuk masyarakat sekitar. Di saat itu Zak Sorga tidak mengikuti kegiatan formal di pesantren melainkan menempuh pendidikan umum mulai dari SDN Beji, SMEP N Tuban, dan SMAN 1 Tuban.

Setelah menghabiskan masa sekolahnya di Tuban yang lekat dengan nilai-nilai keislaman budaya jawa santri, ia membawaberbagai pertanyaantersebut ke bangku perkuliahan, yaitu Institu Seni Jakarta (IKJ). Pendidikannya di tempuh di Jurusan Teater, Institut Kesenian Jakarta (1984). Di tempat barunya ia berhadapan dengan berbagai macam budaya, ideologi dan karakter dari berbagai orang ataupun kesenian, selain itu ia berjumpa dengan nama-nama baru yang lekat dengan pemikiran, sastra, ataupun kesenian, seperti Satre, Arthur Miller, Albert Camus, Beckett, Arifin C Noer, Wahyu Sihombing dan lain-lain, sehingga pada saat itu wawasan Zak Sorga semakin terbuka.

Setelah lama berkecimpung di dunia teater, bapak beranak enam ini bersama dengan beberapa mahasiswa lain di IKJ mendirikan grup teater dengan nama Teater Kanvas pada tahun 1987 yang hingga saat ini masih aktif berkesenian. Dalam proses keseniannya denganTeater Kanvas, Zak Sorga menerapkan pola pendekatan teater dengan penonton. Bahkan, ketika Teater Kanvas mementaskan naskah Intifadah (1992) di Teater Terbuka TIM, ratusan penonton duduk di ruang terbuka meskidi saat yang sama hujan deras mengguyur Teater Arena (TIM). Penonton tetap duduk dan mengikuti jalannya pertunjukan sebab menurut Zak Sorga penononton seakan-akan "mengalami peristiwa" yang sama seperti tokoh-tokoh di dalam pertunjukan.

Selain sebagai seorang sutradara Teater, Zak Sorga juga berperan seabagaipengajar ekstra kurikuler pelajaran Teater di SMA LabschoolRawamangun Jakarta (19871989). Selain itu ia pernah menjadi asisten dosen di Jurusan Teater IKJ dalam mata kuliah: Penyuteradaraan dengan dosen: Suyatna Anirun dan Penulisan Naskah dengan dosen: Tatiek Maliati (1993-1997). Zak Sorga tercatat telah menyutradarai lebih dari 30 buah naskah drama yang sudah dipentaskan di Taman Ismail Marzuki (TIM), Gedung Kesenian Jakarta, beberapa kampus dan kantong- 
kantong kebudayaan di seluruh Indonesia. Beberapa naskah yang pernah ia pentaskan diantaranya Adalah: 'Stasiun Kubur-Kubur' (1985), 'Aljabar' (1987), 'Reuni Orang Orang' (1991), 'Berbiak Dalam Asbak' (1992), 'Konspirasi' (1996), 'Revolusi Burung' (1997), 'Melawan Arus Sepatu' (1999), 'Pemilu Di Desa Gandul' (Sebagai Wakil Indonesia Dalam Festival Seni Enam Negara Tahun 2004/2005 Di Gedung Kesenian Jakarta), dan 'Penghuni Kapal Selam' (2008). Selain berkecimpung di dunia Teater, Zak Sorga juga merupakan pendiri Kelompok Pecinta Tarikh, sebuah Kelompok seni tutur yang menceritakan tentang sejarah perjuangan para pahlawan dan tokoh-tokoh dunia.

Pada tahun 2002 ini, juga menjadi pembicara pada berbagai seminar teater, film dan berbagai workshop seni pertunjukan di beberapa wilayah di Indonesia, yang di jalaninya mulai tahun 1990 hingga saat ini. Zak Sorga juga kerap kali juri pada Festival Teater Jakarta, baik ditingkat penyisihan atau Final. Atas kerja keras dan dedikasinya di bidang teater, ia pernah memperoleh sejumlah penghargaan, diantaranya, tahun 1991, memperoleh penghargaan sebagai Sutradara terbaik dalam Festival Teater Jakarta. Tahun 1992, memperoleh penghargaan sebagai sutradara terbaik dalam Festival Teater Jakarta Di tahun 1993, memperoleh penghargaan sebagai Sutradara terbaik dan penulis naskah terbaik dalam Festival Teater Jakarta.

Selain berkecimpung di dunia panggung ia juga merambah ke bidang film dan sinetron. Pada prosesnya di layar kaca Zak Sorga pernah menyutradarai FTV Ramadhan yang berjudul ' $D A$ ' $I$ ', produksi Prima vision (2002), kemudian ia juga menjadi sutradara FTVyang berjudul 'Rumah Sebelah', produksi Prima vision (2002). Menyutradarai FTV berjudul 'Atas Nama Cinta', produksi Prima vision (2002/2003). Menyutradarai FTV berjudul 'Cermin', produksi Prima vision (2002/2003). Menyutradarai FTV berjudul 'Anakku Sayang', produksi MCU (2005). Menyutradarai FTV berjudul 'Gaya-Gaya Tante Erna', produksi MCU (2005). Menyutradarai film FTV 'Penggemar Utama', produksi MCU (2005). Menyutradarai'Permata Saur' (30 episode) (2006). Selain menyutradarai sinetron, sepanjang karirnya ia juga telah menulis lebih dari 100 skenario TV yang juga sudah ditayangkan di sejumlah stasiun televisi swasta nasional.

Sedangkan kiprahnya di kesenian tradisional adalah dengan menjadi seorang dalang pada kesenian Wayang Daun. Bermula dari acara Mendongeng dan latihan teater yang diselenggarakannya untuk anak-anak di sekitar rumahnya. Dalam dua tahun kesenian tersebut berkembang terutama pada bulan Ramadhan. Sebab dalam kegiatan menunggu berbuka puasadi bulan Ramadhan ia isi dengan 'Dongengan Ala Zak Sorga'yang mennceritakan kisahkisah sahabat nabi.

Tokoh-tokoh dalam wayang daun tidak secara definitif seperti tokoh yang ada pada wayang kulit.Sebab melalui wayang daun yang ia buat, Zak Sorga ingin mendapatkan kebebasan lebih dalam mengekspresikan keseniannya. Oleh sebab itu maka tokoh-tokoh dalam Wayang Daun adalah yang tercipta berdasarkan sifat, seperti Amarah, Santun, Ksatria, atau Seti. Pribadi-pribadi itu bisa menjadi siapa saja dan siapa saja itu adalah sosok-sosok yang benar-benar pernah hidup dan mengukir kehidupan 
realitas manusia. Zak Sorga berharap dengan pakem tersebut, anak-anak mendapatkan sosok teladan yang tidak saja 'besar' tetapi juga nyata. Maka dalam pertunjukannya, tokoh-tokoh wayang daun sering mementaskan Cerita Walisongo, Pangeran Diponegoro, KH Ahmad Dahlan, Bung Tomo, Bung Karno, dan lain-lain. Selain itu melalui wayang daun, ia ingin memadukan seni dan budaya dengan fakta sejarah yang ada. (Teaterkavas.wordpress.com).

\section{Transformasi Ideologi}

Kata ideologi digunakan dalam berbagai macam artian. Istilah ideologi merupakan sebuah kata yang terbentuk dari dua kata, yaitu "ideo" dan "logi". Kata "ideo" berasal dari bahasa Yunani eidos, dalam bahasa Latin idea, yang berarti "pengertian", "ide" atau "gagasan". Kata kerja dalam bahasa Yunani oida yang berarti mengetahui, melihat dengan budi. Ideologi secara istilah lahir pada akhir abad ke-18 atau pada tahun 1796 yang dikenalkan oleh filsuf Perancis yang bernama Destutt de Tracy. Istilah tersebut kemudian dipakai oleh Napoleon Bonaparte. Menurut Destutt de Tracy, ideologi berasal dari dua kata ideos yang berarti gagasan, dan logos yang artinya ilmu. Dengan demikian, ideologi adalah sebuah ilmu tentang gagasan. Berbeda dengan istilah gagasan sebelumnya, gagasan yang dimaksud adalah gagasan tentang masa depan, sehingga bisa disimpulkan bahwa ideologi adalah sebuah ilmu tentang masa depan. Gagasan ini juga merupakan wujud dari cita-citaatau kombinasi dari keduanya, yaitu cita-cita masa depan.

Cita-cita masa depan yang dimaksud merupakan sebuah utopia, atau impian kolektif, tetapi juga sekaligus juga merupakan gagasan ilmiah, rasional, yang bertolak dari analisis masa kini. Ideologi ini tidak sekedar gagasan, melainkan gagasan yang diikuti dan dianut sekelompok besar orang atau bangsa, sehingga ideologi mempnyai sifat untuk mengerakkan manusia agar merealisasikan gagasan atau ide-ide tersebut. Meskipun gagasan seseorang, betapapun ilmiah, rasional atau luhurnya, belum bisa disebut ideologi, apabila belum dianut oleh banyak orang dan diperjuangkan serta diwujudkan, dengan berbagai aksi nyata yang berkesinambungan (Sarbini, 2005: 1).

Pemahaman ideologi pada riset ini merupakan sebuah wujud dari titik tolak penafsiran, titik tolak dalam memproduksi kode/simbol/tanda agar dapat terhindar dari resiko bahaya kekeliruan. Dari titik tolak ini pula, menurut Zoest, dimungkinkan tabir praduga, juga yang berasal dari lambanglambang pertunjukan (Dahana, 2000: 19). Melalui media pertunjukan teater, ideologi tersebut bisa dipertontonkan kepada khalayak, karena komunikasi melalui pertunjukan teater bisa digunakan sebagai komunikasi pendidikan dan budaya pada masyarakat. Secara garis besar, komunikasi pada pertunjukan teater sebenarnya mempunyai pola keterikatan dengan masyarakat melalui pelibatan-pelibatan masyarakat dengan menjadi penonton, serta keterlibatannya dalam mengapresiasi atau mengkritisi melalui penafsiran masyarakat dalam pertunjukan teater. Selain itu hubungan pertunjukan teater dengan masyarakat lebih dilihat dari pola interaksi simbolik, yaitu sebagai suatu kegiatan yang berupa karakter manusia dengan cara berkomunikasi sebagai proses pertukaran simbol yang diberi makna (Mulyana, 
2002:68). James R. Bradon dalam bukunya Theatre in Southeast Asia menjelaskan bahwa; Pada akhir abad ke19 dan awal abad 20 di saat aktifitas penjajahan dilakukan oleh bangsa Eropa dan Amerika diSebagian besar negara Asia Tenggara, para tokoh nasionalis kerap kali memakai seni pertunjukan sebagai media untuk menghidupkan semangat rakyat melawan penjajah. (Soedarsono, 2003: 208-209).

$$
\text { Kata 'transformasi' dalam }
$$
ensiklopedi umum merupakan istilah ilmu eksakta ${ }^{3}$ yang kemudian diperkenalkan ke dalam ilmu sosial yang memiliki maksud perubahan bentuk (Echols, 1992: 801) dan secara lebih rinci memiliki arti perubahan fisik maupun nonfisik (bentuk, rupa, sifat, dan sebagainya) (Qohar, 1998:418419).Pemikir Transformasi Sosial, Byres pada tahun 1984 berpendapat bahwa transformasi adalah suatu perjalanan waktu dan di dalamnya tercakup suatu masa peralihan. Secara semantik, istilah transformasi mengandung arti sebagai sebuah proses perubahan bentuk, dari bentuk yang satu, berubah menjadi bentuk yang lain (Siswanto, 2017: 1).

Pada penjelasan di kajian Teori Piotr Sztompka (2008) mengatakan bahwa dalam transformasi merupakan sebuah perubahan yang tidak hanya dimulai dari luar, melainkan dari dalam (Siswanto, 2017: 3). Teori ini dapat dilihat dari

3 Di dalamnya terdapat pembagian istilah seperti; transformasi Linier, transformasi Affindan transformasiOrthogonal serta terdapat juga istilah transformator. Selanjutnya lihat; Prof. Mr.A.G Pringgodigdo, EnsiklopediUmum, (Yogyakarta: Yayasan Kanisius, 1973), hlm. 1354. penilitian yang penulis lakukan terhadap idologi pertunjukan Teater Kanvas. Melalui pertunjukan-pertunjukan yang sudah dilakukan Teater Kanvas penulis meneliti melalui berbagai naskah pertunjukan baik yang naskah awal-awal pertunjukan, transisi maupun naskah pertunjukan di era terdekat ini. Selain melalui analisis naskah, melalui dokumentasi pertunjukan dan wawancara terhadap stakeholder Teater Kanvas dapat dilihat bagaimana proses transformasi tersebut terjadi.

Pada proses transformasi waktu dan sosok merupakan dua hal yang tidak dipisahkan. Melalui waktu, baik waktu secara kuantitas ataupun kualitas mempunyai porsi besar dalam perubahan ideologi Pertunjukan Teater Kanvas, sebab transformasi tidak serta merta terjadi tanpa adanya proses pergesaran waktu. Selain waktu sosok merupakan sebuah hal lain yang juga mempengaruhi proses sebuah transformasi. Dalam proses transformasi ini Zak Sorga merupakan sosok yang berpengaruh terhadap proses perubahan ideologi pertunjukan Teater Kanvas. Sebab, selain merupakan sutradara tetap Teater Kanvas, ia juga merupakan pendiri dari teater tersebut.

Dalam meneliti proses transformasi ini penulis membagi penelitian ini menjadi tiga bagian, yaitu Ideologi pertunjukan awal, konsep waktu dan pengaruh sosok dalam perubahan ideologi pertunjukan Teater Kanvas. Melalui ketiga hal tersebut penulis melihat bagaimana sebuah proses transformasi terjadi.

\section{Ideologi Awal Teater Kanvas}

Sebagaimana pembahasan di bab sebelumnya, yang merujuk pada hasil wawancara dengan Zak Sorga serta 
berbagai berita yang penulis dapatkan melalui potongan-potongan kliping pembirtaan terkait dengan Teater Kanvas. Pada dasarnya Teater Kanvas merupakan sebuah Teater Ideologis, hal ini ditunjukan dengan kuatnya nilai-nilai spiritualisme yang ada di dua pertunjukan awal Teater Kanvas, yaitu Stasiun KuburKubur (1988) dan Aljabar (1990). Namun ideologi yang dimaksud penulis dalam penelitian ini merupakan sebagai sebuah titik tolak interpretasi, titik tolak dalam memproduksi kode/simbol/tanda dapat terhindar dari resiko bahaya kekeliruan. Dari titik tolak ini pula, menurut Zoest, dimungkinkan tabir prasangka, juga yang berasal dari lambang-lambang pertunjukan (Dahana, 2000: 19).

Pada penelitian ini untuk melihat sebuah ideologi pertunjukan penulis menganalisa melalui hasil wawancara terhadap narasumber.Dalam hal ini wawancara tersebut dilakukan kepada pendiri, pemain dan penonton pertunjukan Teater Kanvas. Selain melalui wawancara penulis juga menganalisa naskah-naskah pertunjukan awal Teater Kanvas dan juga berbagai liputan media cetak pada masa itu. Dalam proses wawancara belum ada narasumber yang secara spesifik membicarakan ideologi awal Teater Kanvas, yang jelas mereka sepakat bahwa ideologi awal Teater Kanvas bukan ideologi yang berwarna Islami, Politik Islam ataupun Dakwah Islam. Afrizal Malna (2020) dalam wawancaranya tidak secara gamblang menjawab tentang ideologi awal Teater Kanvas, dia hanya menyatakan bahwa Teater Kanvas merupakan sebuah kelompok-kelompok Teater Urban yang banyak bermunculan di masa itu (akhir 80-an). Selain itu Azuzan (2020) yang merupakan aktor di masa awal Teater
Kanvas bahkan menyebut Teater Kanvas sebagai kelompok teater yang sekuler.Dalam data wawancara yang penulis dapatkan, hanya Zak Sorga selaku sutradara/pendiri Teater Kanvas yang menyatakan tentang ideologi awal yang mewarnai pertunjukan Teater Kanvas.

Menurut Zak Sorga, pijakan Ideologi awal Teater Kanvas adalah spiritualisme, atau lebih tepatnya spiritualisme dalam pewayangan. Ideologi tersebut berhubungan dengan latar belakang Zak Sorga yang semasa kecilnya sering bersentuhan dengan dunia pewayangan, sehingga spiritualisme pewayangan mempunyai pengaruh terhadap pertunjukan di masa-masa awal berdirinya Teater Kanvas. Hal ini juga terasa pada beberapa naskah di awal berdirinya Teater Kanvas.

Dalam kurun waktu tiga tahu setelah berdirinya Teater Kanvas. Kelompok tersebut sudah mementaskan tiga naskah pertunjukan, yaitu Stasiun Kubur-Kubur (1988) karya dan sutradara Zak Sorga, Oedipus di Colonus (1989) karya Sastra Sophocles, pujangga besar Yunani Kuno, pada 450 tahun Sebelum Masehi dan diterjemahkan oleh WS Rendra serta disutradarai oleh Dani salah seorang anggota Teater Kanvas, dan naskah pertunjukan Aljabar (1990) karya dan sutradara Teater Kanvas. Melalui pertunjukan Stasiun Kubur-Kubur (1989) Teater Kanvas mengambil pendekatan realis yang menceritakan tentang kegelisahan seorang anak muda yang tinggal di stasiun yang mempertanyakan tentang hidup, tentang Tuhan dan tentang kematian. Berbagai pertanyaan filosofis tersebut disajikan kepada penonton sehingga menimbulkan katarsis terhadap penonton. Sedangkan pementasan kedua merupakan karya Sopochles "Oedipus 
Sang Raja" mengungkap suatu lakon tragedi-romantik yang mengisahkan perjalanan hidup "Putra nasib" Oedipus dalam mengalami kebesaran dan keruntuhannya. Selanjutnya adalah pementasan naskah pertunjukan Aljabar (1990) merupakan sebuah gambaran perspektif kehidupan melalui dua aktor yang berperan menjadi dua tokoh pelukis yang mempunyai latar belakang dan usia yang berbeda.

Dari tiga naskah awal tersebut, naskah pertunjukan Stasiun Kubur-Kubur (1987) dan Al-jabar (1990) menjadi sebuah representasi dari spiritualisme pewayangan yang dimaksud oleh Zak Sorga. Hal ini dapat dilihat melalu beberapa dialog yang terdapat pada kedua naskah tersebut. Pada naskah pertunjukan Stasiun Kubur-Kubur (1987). Pada naskah pertunjukan Stasiun Kubur-Kubur ditampilkan sebuah keresahan tentang pencarian hidup anak muda yang bernama Murat melalui dialognya dengan beberapa tokoh, salah satunya dengan tokoh Rantam. Pada salah satu dialog tokoh Murat menyatakan bahwa kehidupan mereka bagaikan wayang tanpa tokoh, melewati hutan kehampaan, tidak ada hiasan batin. Jika dicermati secara denotasi ekspresi (E1) murat menggambarkan kegelishan yang terkait (R1) dengan realita hidup yang penuh kegetiran (C1). Namun secara konotasi, peristiwa ini terkait dengan kondisi batiniah seorang tokoh (Murat) yang sedang berproses menjalani sebuah kehidupan. Perisitiwa tersebut erat kaitannya dengan salah satu falsafah Jawa yang terdapat pada dunia pewayangan yaitu Sangkan Paraning Dumadi. Falsafah tersebut merupakan sebuah pelajaran tentang bagaimana manusia menjalani sebuah kehidupan, sampai tujuan akhirnya adalah menuju Tuhan. Selain itu diksi wayang yang dimaksud oleh Murat bukan sekadar wayang yang dimainkah oleh dalang, melainkan sebagai sebuah cerminan dari kehidupan manusia di masyarakat.

Selain pada naskah pertunjukan Stasiun Kubur-Kubur, nilai-nilai spiritualisme pewayangan juga terasa pada naskah Al-Jabar.Hal tersebeut dapat dilihat melalui dialog yang dibangun antara kedua tokoh, dalam hal ini melalui tokoh "Orang 1" yang merupakan simbol tokoh muda, dengan "Orang 2" yang merupakan gambaran dari orang tua yang syarat akan pengalaman dan kebijaksanaan.Kedua tokoh tersebut bergantian melempar dialog yang berisi keresahankeresahan terhadap rutinitas hidup yang mereka lakukan. Orangtua dan orang muda dalam naskah tersebut juga terdapat dalam pewayangan, seperti bagaimana peran panakawan yang secara tidak langsung berperan menjadi sosok orangtua yang mengayomi pandawa yang dapat diasosiasikan sebagai simbol anak muda yang butuh dibimbing agar senantiasa berbuat kebaikan.

Secara denotasi, muda dan tua merupakan sebuah fase dalam kehidupan dan perjalanan manusia, namun secara kontoasi anak muda banyak diartikan sebagai sebuah ikon perubahan zaman, meskipun begitu anak muda juga digambarkan sebagai sosok yang tidak stabil, berbeda dengan orangtua yang merupakan gambaran dari kearifan karena pengalaman hidupnya yang lebih Panjang.Melalui kedua karakter tersebut, pertunjukan Al-Jabar tidak hanya menyajikan satu identitas ideologi melainkan beberapa gagasan sehingga belum menurut penulis di fase ini Teater Kanvas belum ajeg konsisten berdiri pada satu 
ideologi tunggal, meskipun begitu warna spiritualisme pewayangan mampu mewakili berbagai ideologi yang muncul pada pertunjukan di masa-masa awal Teater Kanvas.

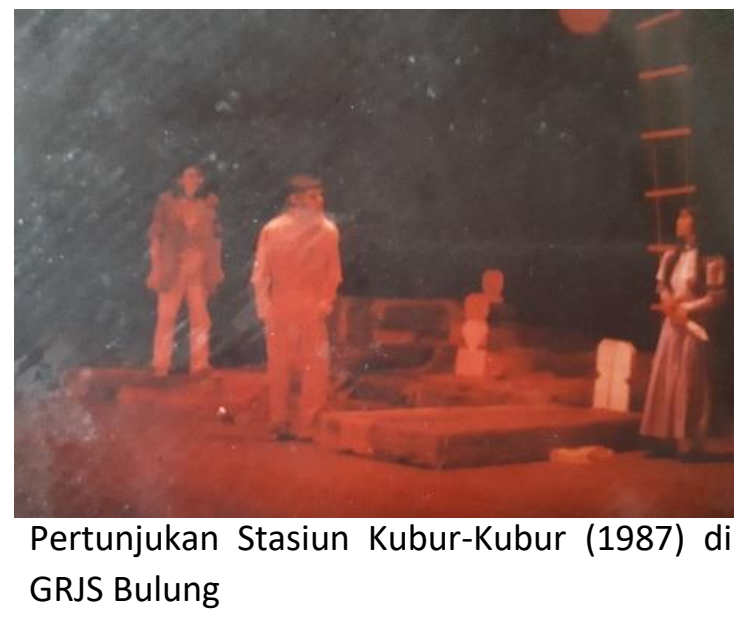

\section{Masa Transisi Transformasi Ideologi}

Dalam proses transformasi, aspek internal dan eksternal merupakan sebuah faktor penting dalam proses transformasi tersebut. Pada konteks Ideologi pertunjukan Teater Kanvas, aspek internal dan eksternal transformasi ideologi pertunjukan dapat dilihat melalui konsep waktu, serta sosok yang menjadi agen perubahan ideologi pertunjukan Teater Kanvas. Pada konteks transformasi ideologi pertunjukan Teater Kanvas waktu berperan besar terhadap perubahan yang terjadi pada ideologi kelompok tersebut, baik secara internal ataupun eksternal. Secara eksternal, waktu kuantitatif berperan penting atas perubahan yang terjadi pada suatu objek penelitian. Pada konteks transformasi ideologi pertunjukan Teaer Kanvas, waktu sebagai kuantitas dapat dilihat dari proses perkembangannya.

Pada prosesnya transformasi ideologi pertunjukan Teater Kanvas dapat dilihat dalam beberapa fase. Hal ini dilihat dari beberapa pertunjukan awal
Teater Kanvas hingga pertunjukannya yang terkini. Dalam kurun waktu yang terhitung secara waktu kuantitatif ada beberapa fase dalam proses transformasi ideologi pertunjukan Teater Kanvas, fase awal, fase pertengahan dan fase akhir. Pada fase awal merupakan sebuah fase pencarian ideologi perunjukan dan merupakan pijakan awal transformasi tersebut. Tahap selanjutnya adalah proses transisi transformasi ideologi pertunjukan. Di fase akhir merupakan sebuah fase di mana transformasi sudah terjadi. Berbagai fase tersebut tergambar dalam berbagai tanda yang penulis temukan melalui proses wawancara, analisa naskah pertunjukan, dan analisa pemberitaan Teater Kanvas melalui berbagai media.

Fase awal merupakan sebuah landasan dari proses sebuah transformasi ideologi pertunjukan Teater Kanvas. Sebagaimana pembahasan di sub-bab sebelumnya, yaitu mengenai pembahasan ideologi awal pertunjukan Teater Kanvas, pada fase ini merupakan sebuah proses pencarian ideologi, dan momen penting untuk ke tahap transformasi. Sebab transformasi tidak akan pernah terjadi tanpa adanya form awal dari sebuah objek, dan dalam konteks penelitian ini objeknya adalah Teater Kanvas.

Secara waktu sebagai kuantitas, proses ini memakan waktu selama 4 tahun. Di mulai dari awal pendiriannya di tahun 1987, hingga 1990. Dalam kurun kurun waktu tersebut, sebagaimana pembahasan di sub-bab sebelum ini, Teater Kanvas masih mencari sandaran ideologi untuk pertunjukannya, meskipun begitu ideologi spiritualisme pewayangan cukup banyak mewarnai fase awal Teater Kanvas. Melalui proses pencarian tersebut Teater Kanvas sudah mempertunjukan tiga naskah pertunjukan 
yang berbeda secara gagasan, ataupun secara garapan pertunjukan. Dalam fase ini ada berbagai macam unsur ideologis yang melekat pada pertunjukan Teater Kanvas, mulai dari alienasi, spiritual, humanisme, hingga unsur agama muncul pada naskah-naskah awal pertunjukan Teater Kanvas yaitu pada pertunjukan Stasiun Kubur-Kubur (1988), Oedipus (1989) dan Aljabar (1990).

Fase selanjutnya merupakan fase penting dalam proses transformasi ideologi pertunnjukan Teater Kanvas. Pada fase ini penulis melihat Teater Kanvas sudah mulai konsisten dalam memunculkan berbagai simbol terkait dengan nilai dakwah, meski masih dibalut dengan humanism. Hal ini tergambar melalui beberapa pertunjukan Teater Kanvas dalam kurun waktu tiga tahun (1991-1993), yaitu melalui pertunjukan Reuni Orang-Orang (1991), Berbiak dalam Asbak (1992), dan Di Luar Ruang (1993). Melalui ketiga naskah ini Zak Sorga melalui Teater Kanvas sudah mulai menyentuh isu-isu yang terkait dengan Islam, terutama Islam dalam konteks Geopolitik.

Pada fase ini simbol Islam muncul melalui nilai-nilai perjuangan yang terdapat pada kritikan Teater Kanvas terhadap situasi global yang terjadi di saat itu, seperti berbagai konflik yang menyudutkan umat Islam seperti IsraelPalestina, Iran-Iraq, ataupun BosniaSerbia. Meskipun pada fase tersebut juga terdapat berbagai gagasan ataupun ideologi dalam pertunjukannya, namun simbol Islam secara konsisten disisipkan, baik melalui nama tokoh, dialog ataupun adegan-adegan yang terdapat pada beberapa pertunjukan di kurun waktu tersebut. Dalam fase ini titik puncak transformasi ideologi pertunjukan terlihat dalam naskah pertunjukan.

Salah satu momen penting dalam fase ini adalah pada pertunjukan Di Luar Ruang (1993). Naskah ini merupakan sebuah proses yang menjembatani pencarian ideologi pertunjukan Teater Kanvas sampai akhirnya kelompok teater tersebut secara konsisten. Sebab selain memunculkan simbol Islam melalui dialog, monolog, ataupun tokoh-tokoh yang merepresentasikan dunia Islam, pada naskah pertunjukan ini Teater Kanvas mulai menerapkan ajaran-ajaran Islam yang mereka pahami dalam pertunjukan mereka, seperti memberikan hijab (batas) antara penonton laki-laki dan perempuan. Selain beberapa hal tersebut, dalam pertunjukan Di Luar Ruang, Teater Kanvas hanya menggunakan pemain laki-laki untuk menghindari bersentuhannya laki-laki dan perempuan dalam adegan pertunjukan tersebut. Proses di pertunjukan Di Luar Ruang sendiri merupakan sebuah pencarian Zak Sorga yang di saat itu sedang bersentuhan dengan kajian Islam di Masjid Amir Hamzah.

Selanjutnya adalah fase terakhir, yang merupakan penegasan tentang ideologi pertunjukan Teater Kanvas. Pada fase ini Teater Kanvas sudah mendeklarasikan bahwa ideologi pertunjukannya dakwah Islam. Hal ini dapat dilihat dari pemilihan naskah, tema, ataupun nilainilai perjuangan Islam yang dapat dilihat melalui pesan-pesan yang terdapat pada berbagai pertunjukan Teater Kanvas pasca transformasi ideologi. Beberapa naskah awal pada fase ini syarat akan perjuangan umat Islam.

Beberapa naskah pertunjukan di fase ini antara lain seperti pertunjukan Intifadhah (1994), tentang perlawanan 
Palestina terhadap Israel, Mencari Keadilan (1995) yang merupakan salah satu karya sastra dari Yusuf Qardhawi (1995), Konspirasi (1996), tentang pergulatan politik di Turki, dan Revolusi Burung (1997), tentang gambaran dunia pendidikan di Indonesia. Melaui naskahnaskah tersebut Teater Kanvas secara konsisten menyuarakan dakwah Islam melalui naskah-naskah tersebut.

Melalui ketiga fase tersebut, dapat dilihat bagaimana peran waktu kuantitatif dalam mengukur peristiwa dan proses yang terjadi baik di dalam ataupun di luar panggung, serta dalam menata kesemrawutan aliran peristiwa dan proses demi orientasi manusia untuk mengoordinasikan tindakan yang terjadi dalam aspek ideologi pertunjukan yang Teater Kanvas lakukan.

Selain waktu sebagai kuantitas, dalam proses transformasi ideologi pertunjukan Teater Kanvas waktu kualitas juga menjadi aspek penting dalam konteks perubahan. Untuk mencapai sebuah pemahaman ataupun ideologi baru, selain melalui fase perubahan secara kuantitas yang tersistem menjadi beberapa waktu, dibutuhkan juga perpaduan waktu dan perubahan sosial sehingga tidak lagi sekadarr kerangka konvensional atau eksternal tetapi sebagai kerangka internal peristiwa sosial dan proses tersebut dinamakan dengan waktu kualitas.

Pada konteks Teater Kanvas, transformasi ideologi dilihat bukan hanya melalui aspek perubahan eksternal yang dilihat dari berbagai fase waktu perubahan tersebut, melainkan juga melalui aspek internal yang dilatarbelakangi oleh waktu sebagai kualitas. Dalam hal ini untuk melihat proses transformasi tersebut bukan hanya melalui perubahan angka-angka sistematis, melainkan sebuah proses yang dapat dilihat dari, panjang-pendek, cepatlambat, ritme yang acak, dan potonganpotongan kejadian yang akhirnya menimbulkan perubahan sebuah ideologi.

Proses transformasi Teater Kanvas sendiri tidak lepas dari keempat hal di atas dandalam prosesnya perubahan ideologi Teater Kanvas terjadi dalam kurun waktu yang tidak terlampau lambat.Sebab jika dilihat salah satu aspek internal transformasi ideologi Teater Kanvas adalah proses pencarian Zak Sorga selaku pendiri dan mempengaruhi aspek-aspek lain di dalam Teater Kanvas, baik dari segi aktor, garapan, cerita bahkan akhirnya sampai ke segmentasi penonton. Pencarian Zak Sorga tersebut merupakan salah satu dari pecahan peristiwa Transformasi Ideologi pertunjukan Teater Kanvas, sebagaimana potongan-potongan peristiwa lain, seperti realitas sosial yang terjadi di masyarakat ataupun peristiwa geopolitik di dunia sampai akhir potongan-potongan tersebut seiring waktu membentuk ideologi pertunjukan baru.

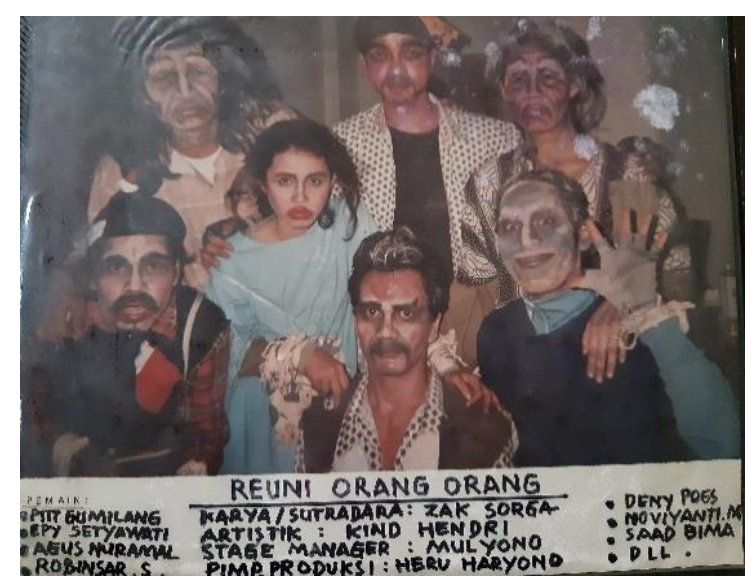

Para Aktor di Pementasan Reuni Orang-Orang

Menuju Ideologi Dakwah Teater
Kanvas 
Setelah melalui berbagai fase dalam proses transformasi ideologi pada akhirnya Teater Kanvas secara tegas mendeklarasikan dakwah Islam sebagai ideologi pertunjukannya. Dalam sejarah perkembangan Teater di Indoneisa ada beberapa kelompok teater yang beberapa kali mengangkat tema Islam dalam pertunjukannya, seperti Teater Muslim (Yogyakarta), Teater Mahasiswa Islam (Yogyakarta), Teater Himpunan Seni Budaya Islam (Jakarta), dan Teater Cuwiri (Pekalongan). Setelah berbagai era tersebut Teater Kanvas melanjutkan tongkat estafet sebagai kelompok teater yang mengangkat nilai-nilai keislaman dalam pertunjukannya.

Ideologi dakwah Islam Teater Kanvas dapat dilihat bukan hanya dalam sudut internal pertunjukan, melainkan juga pada beberapa aspek eskternalnya. Setelah fokus terhadap dakwah, beberapa pertunjukan mempunyai nafas Islam sebagai simbol perlawanan, hal ini dapat dilihat dalam beberapa pertunjukannya, di antara lain; Intifadah (1994), dan Mencari Keadilan (1995) tentang perlawanan Palestina terhadap Israel, Konspirasi (1996), tentang pergulatan politik di Turki, Revolusi Burung(1997) kritikan terhadap pendidikan di Indonesia, Blangwir Nyelonong di Priok (1998) yang bercerita tentang tragedi Tanjung Priok, dan beberapa pertunjukan politis seperti Melawan Arus Sepatu (1999), Pemilu di Desa Gandul (2004), serta Penghuni Kapal Selam (2004). Berbagai pertunjukan tersebut tidak hanya bermuatan pesan-pesan yang Islami, melainkan juga dikemas secara Islami, yaitu dengan menggunakan pemain yang semuanya laki-laki dan memisahkan penonton laki-laki dan perempuan sebagaimana menjalankan konsep mahram yang ada dalam Islam.

Jika dilihat dari pesan-pesan yang disampaikan terdapat sebuah pembeda dari beberapa pementasan Teater Kanvas pasca transformasi. Dalam aspek waktu, di beberapa pertunjukan awal pola kritikannya cenderung ke arah politik global yang memojokkan Islam, seperti di naskah Menumbangkan Kezaliman (1994) yaitu naskah karya Yusuf Qardhawi yang dipentaskan Zak Sorga bersama MIMAZAH (Remaja Masjid Amir Hamzah) yang erat dengan nilainilai perjuangan di Palestina, lalu pada naskah Intifadhah (1994) dan Mencari Keadilan (1995) yang juga mengangkat cerita tantang Palestina, dan pada naskah Konspirasi (1996) yang bercerita tentang pergulatan tentang pertentang ideologi politik antara Islam dan Sekuler di negara Turki. Namun seiring melemahnya kekuatan rezim orde baru, Teater Kanvas mulai menyentuh kritikan-kritikan terhadap rezim Presiden Soeharto, hal ini tergambar dari tiga naskah yang muncul di akhir dan awal rezim orde baru, seperti; Revolusi Burung (1997) yang mengritik tentang sistem pendidikan di Indonesia, Blangwir Nyelonong di Priok (1998) yang mengambil cerita seputar tragedy Priok pada tahun 80-an, dan Melawan Arus Sepatu (1999) yaitu tentang perjuangan aktifis reformasi. Namun meskipunterdapat perbedaan pola kritik dalam beberapa pertunjukannya, namun benang berahnya masih sama, yaitu lekatnya ideologi dakwah Islam dalam pertunjukan Teate Kanvas.

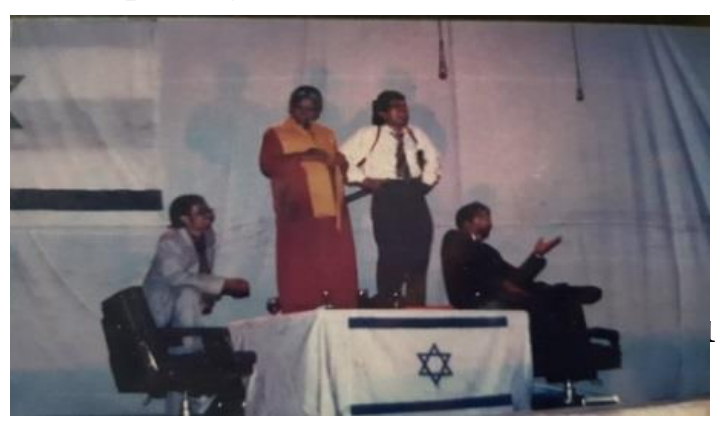


Pementasan Intifadhah (1994) yang merupakan sebuah simbol

Selain dilihat melalui berbagai aspek eksternal seperti berbagai unsur di dalam pemanggungan, nilai dakwah Islam juga diterapkan Teater Kanvas dalam aspek internal kelompok mereka. Di antaranyamelalui proses latihan yang dilakukan oleh Teater Kanvas, seperti memulai dan mengakhiri latihan dengan berdoa secara Islam. Selain itu Teater Kanvas mewajibkan anggotanya untuk sholat jika suara azan terdengar. Selain itu Zak Sorga selaku pendiri dan sutradara Teater Kanvas kerap mengajak anggota Teater Kanvas untuk mengikuti kajian seputar agama Islam.

Pasca transformasi ideologi pertunjukan Teater Kanvas, penonton Teater Kanvas menjadi tersegmentasi. Jika dibandingkan beberapa pertunjukan kelompok teater lain di Jakarta, penonton teater kanvas kebanyakan adalah kelompok islamis, seperti kelompok ibuibu pengajian, sekolah-sekolah Islam ataupun ikhwan dan akhwat. Selain penonton yang tersegmentasi, salah satu dampak dari transformasi ideologi pertunjukan Teater Kanvas adalah kedekatan kelompok tersebut dengan salah satu partai politik berbasis Islam di Indonesia yaitu PKS (Partai Keadilan Sejahtera). Hal ini dapat dilihat dari beberapakali keterlibatan Teater Kanvas dalam kegiatan PKS, dan antara PKS dan Teater Kanvas pernah bekerjasama dalam mementaskan pertunjukan yaitu pementasan ulang Penghuni Kapal Selam yang dilaksanakan di Gedung Kesenian Jakarta, pada tahun 2014.
Transformasi Teater Kanvas tidak bisa dilepaskan dari perubahan sikap pemerintah Orde Baru terhadap Islam. Di akhir masanya, pemerintah Orde Baru mulai merapat ke gerbong umat Islam. Hal ini ditandai dengan munculnya Ikatan Cendikiawan Muslim (ICMI), dan munculnya gerakan Islam di masjidmasjid kampus, dan salah satunya adalah di Masjid Amir Hamzah yang berada di komplek Institut Kesenian Jakarta. Melalui gerakan Tarbiyah yang berbentuk kajian-kajian keislaman ini yang secara tidak langsung mendorong Zak Sorga untuk menyuarakan Islam di dalam pertunjukan Teater Kanvas.

Sosok agen perubahan dalam proses transformasi ideologi pertunjukan Teater Kanvas adalah Zak Sorga, pendiri, penulis naskah sekaligus sutradara Teater Kanvas. Perubahan ideologi Teater Kanvas tidak serta merta terjadi begitu saja, melainkan melalui pencarian dan pengalaman masa kecil Zak Sorga. Peran historis Zak Sorga dalam berbagai fase perubahan terlihat melalui berbagai tawarannya dalam berbagai naskah pertunjukan yang ia buat, mulai dari fase pencarian ideologi (1987-1990), fase transisi (1991-1993), dan fase ideologi dakwah Islam (1994 - sekarang).

Hook membedakan orang besar menjadi: individu luar biasa dan individu ciptaan luar biasa. Tipe pertama besar karena karyanya sendiri. Kebesarannya bukan karena derajat kebijakan, imajinasi atau integritas moral yang luar biasa. Sedangkan tipe yang kedua, ia besar karena kebesarannya. Manusia ini mencerminkan kualitas otak dan perasaan luar biasa: cerdas, pandangan yang jelas, keyakinan kuat, tekun dalam mengikuti tujuannya dan bercakapan pemimpin (Stompzka, 2017:302). 
Dalam konteks Zak Sorga, ia merupakan orang besar tipe pertama. Hal ini dapat dilihat bagaimana ia mengubah ideologi kelompoknya melalui imajinasi yang ia bangun melalui naskah ataupun pertunjukan Teater Kanvas. Selain itu pengalaman dan aspek lingkungan semasa kecil dan remaja di Tuban yang cukup kental dengan unsur religi, turut serta mempengaruhi landasan transformasi ideologi pertunjukan Teater Kanvas. Ditambah dengan aktivitas Zak Sorga di dalam kegiatan pengajian di Masjid Amir Hamzah, yang menjadi pemicu bagi Teater Kanvas untuk mendeklarasikan Ideologi dakwah Islam dalam pertunjukannya. Dan melalui karya-karyanya Zak Sorga tidak sekadar mengubah ideologi namun juga memperkaya khazanah perteateran di Indonesia dengan konsistensinya dalam menyebarkan dakwah Islam melalui media Teater.

\section{Penutup}

Teater Kanvas merupakan sebuah kelompok teater yang sudah berproses cukup lama di wilayah Jakarta. Berawal dari kumpulan mahasiswa yang ingin mengekspresikan diri melalui wadah teater, akhirnya pada tahun 1987 terbentuk sebuah kelompok teater yang bernama "Kanvas." Pada awalnya kelompok ini masih mencari ideologi dalam pertunjukan teater yang mereka bawakan. Dalam proses pencarian tersebut Teater Kanvas kerap kali menyentuh beberapa ideologi seperti; eksistensialisme, alienasi, spiritualisme, dan humanism.Namun seiring waktu Teater Kanvas pada akhirnya bertransformasi dan secara tegas menyatakan kelompok ini merupakan teater yang berideologi dakwah Islam.
Dalam prosesnya, transformasi ideologi pertunjukan Teater Kanvas dapat dilihat melalui dua hal yaitu waktu, dan sosok agen perubahan. Pada aspek waktu perubahan tersebut dilihat melalui dua perspektif, yaitu waktu sebagai kuantitas, dan waktu sebagai kualitas. Waktu kuantitas dalam proses transformasi ideologi pertunjukan Teater Kanvas dapat dilihat melalui tiga fase; fase awal (19871990), fase transisi (1991-1993), dan fase akhir (1994 - sekarang). Sedangkan waktu dalam perspektif kualitas dapat dilihat dari prosesnya. Pada konteks Teater Kanvas, transformasi ideologi dilihat melalui proses pencarian Zak Sorga selaku pendiri dan mempengaruhi aspek-aspek lain di dalam Teater Kanvas, baik dari segi aktor, garapan, cerita bahkan akhirnya sampai ke segmentasi penonton. 


\section{$\underline{\text { Daftar Pusataka }}$}

Dahana, Radhar Panca. 2000. Ideologi Politik dan Teater Modern Indonesia. Magelang: Indonesiatera.

Danarto. 1998. Teater Politik Praktis. Tempo (8 Desember 1998).

Denzin, Norman K. dan Yvonna S. Lincoln (eds.). 2009. Handbook of Qualitative Research. Terj. Dariyatno dkk. Jogjakarta: Pustaka Pelajar.

Echols, John. M dan Hasan Shadily. 1992. Kamus Bahasa InggrisIndonesia. Jakarta: Gramedia.

Emzir. 2012.Metodologi Penelitian Kualitatif, Analisis Data. Jakarta: PT Raja Grafindo.

Kususmawati, Aning Ayu. 2009. "Menengok Seni Teater/Drama Umat Islam Di Indonesia." Adabiyyat, Vol. 8, No. 2.

Lull, James. 1998. Media Komunikasi Kebudayaan Status Pendekatan Global. Jakarta: Buku Obor.

Sumardjo, Jakob. 1966. Ikhtisar Sejarah Teater Barat. Bandung: Penerbit Angkasa.

Mulyana, Deddy. 2002. Metodologi Penelitian Kualitatif: Paradigma Baru Ilmu Komunikasi dan Ilmu Sosial Lainnya. Bandung: Rosdakarya.

Qohar, Mas'ud Khasan Abdul. 1998. Kamus Ilmiah Populer. Gresik: Bintang Pelajar.

Rustanto, Bambang. 2015. Penelitian Kualitatif Pekerjaan Sosial. Bandung: Rosda Karya.

Salad, Hamdy. 2000. Agama Seni Refleksi Teologis Dalam Ruang Estetik. Yogyakarta: Yayasan Semesta.

Sibarani, Robert. 2012.Kearifan Lokal, Hakikat Peran dan Metode Tradisi Lisan. Jakarta: ATL
Siswanto, Budi. 2017. Transformasi Sosial. Palangka Raya: Penerbit Lembaga Literasi Dayak.

Spradley, James P. 2007. Metode Etnografi. Yogyakarta: PT. Tiara Wacana Yogya.

Sudarsono, M. 2003. Seni Pertunjukan dari Perspektif Politik Sosial dan Ekonomi. Yogyakarta: Gajah Mada University Press.

Sugiyono. 2017. Metode Penelitian Kuantitatif, Kualitatif, dan R \& D Bandung: IKAPI.

Sztompka, Piotr. 2017. Sosiologi Perubahan Sosial. Jakarta: Kencana. 